\title{
Increasing the physical and economic size of agricultural holdings - necessity to reduce disparities between Romania and the European Union
}

\author{
Adrian Turek Rahoveanu
}

\begin{abstract}
After 1990, Romanian agriculture has undergone a long process of transition from command to market economy to adapt to the operation of the common market for integration into European structures and subsequently in 2007 to implement the Common Agricultural Policy. In terms of operational structures Romanian agriculture is uneven, and their dual nature is emphasized to the vast majority of Member States of the European Union. In Romania, the agricultural land fund is strongly affected by the fragmentation into small parcels, which leads in many cases impossible the application of modern agricultural technologies leading agricultural technology, scientifically, to obtain Farmland of stable production both in terms of quantity and quality.
\end{abstract}

Keywords-agrarian structures, farm management, sustainable growth, competitiveness

\section{Introduction}

European agriculture is very diverse, both in terms of farm structure and production methods and land use. The diversity of agriculture in the European Union on the one hand reflects the historical development but is mainly dependent on natural conditions: climatic, geographical, geological and socio-economic environment of each State. In Romania agriculture is a very important sector, both by the contribution that has national economy and by its social role. The current state of the Romanian agriculture, the countryside, in large part, is determined by the agrarian structure of Romania - economic and social issues of the utmost importance and actuality for Romania.

Agrarian structures necessary basic training and operation of competitive market constitutes a system of interdependent components and flexible in time and space related to: economic organization of farmers into viable forms of exploitation, formation of production structures according to requirements consumer technical and technological modernization of farms to obtain quality products at competitive prices, organizing marketing structures so as to ensure over distribution channels and supply the necessary material and financial flows resuming production training foodservice channels, complex and sustainable rural development [1].

Adrian Turek Rahoveanu

University of Agronomic Sciences and Veterinary Medicine of Bucharest Romania
With its accession to European Union agricultural policies that have been applied in Romania were the result of interaction between CAP and national agricultural policy measures, which complemented programs. However, the competitiveness of the agricultural sector in Romania, analyzed in terms of performance farms, following the old Member States of the European Union.

Increase domestic agricultural production is the main factor that affects food security and agricultural policies of the country. Farm structure adjustment measures are tools that have the potential to bring a lasting solution to the problem of agricultural supply, including by supporting economic growth and physical size of holdings, in line with the developments in technology used in agricultural production.

Comparing the economic performance of farms of different sizes between Romania and the EU member countries shows that Romania is only at the beginning of the road to a modern agriculture.

\section{Materials and Methods}

This paper aims to present an objective analysis of the agricultural sector in Romania, focusing on the development directions of physical and economic size of farms and the need to introduce measures to strengthen their.

The main elements of the work were to evaluate the situation of Romanian agriculture compared to other EU member states, identifying alternative economic efficiency of farms, focusing on increasing the average size of the farm and the necessary changes in the production structure.

The data used for analyzes in this paper come from various sources, both national origin (National Institute of Statistics, Ministry of Agriculture and Rural Development) and international (Eurostat, European Commission) and generally include: statistics holdings, Economic Accounts for Agriculture, farm structure.

\section{Results and Discussions}

Romania to the EU presents significant gaps in productivity of the agricultural sector. Even in the favorable agricultural productivity level is below $50 \%$ of the EU average situation showing untapped economic potential of Romanian agriculture and rural areas. This can be explained both by the internal structure of Romanian farms (small size, fragmentation pronounced), inappropriate use of inputs (including human capital) and the existing poor infrastructure [16]. 
Proc. of the International Conference on Advances in Management, Economics and Social Science - MES 2016 Copyright (C) Institute of Research Engineers and Doctors. All rights reserved.

ISBN: 978-1-63248-103-0 doi: 10.15224/ 978-1-63248-103-0-76

\section{The number and size agricultural holdings}

According to Eurostat, the EU-28 were recorded in 2014, a total of almost 12 million farms. These farms covering an area of 170 million hectares, average farm is 14.2 ha. In Romania there were 3.86 million farms, employing 13.3 million ha UAA returned the average holding is 3.45 ha, more than 4 times lower than the EU average, which negatively influences the implementation worth of agricultural and rural resources available, with adverse effects on the rural economy and farmers' incomes [5].

The structure of agriculture in Europe are however stark contrasts: on one side there is a large number (6018 thousand holdings) of very small farms (less than 2 hectares), which uses a small percentage $(2.5 \%)$ of the surface all of the fields (4.3 million hectares), and on the other hand, there is a small (2.7\% of total holdings) of large farm (100 ha), using the 87.424 thousand hectares $(50.2 \%)$ of the total land area used in the EU-28, Figure 1, Figure 2) [13].

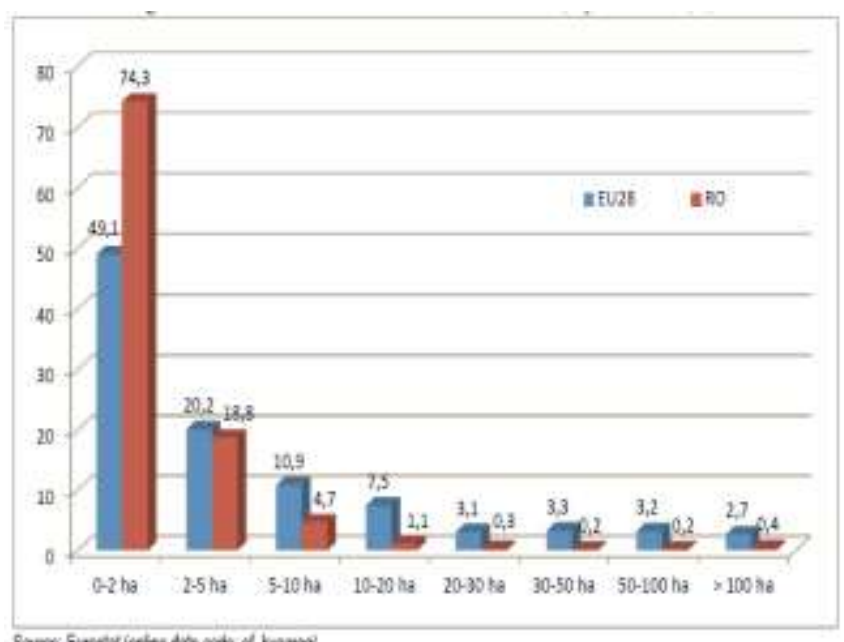

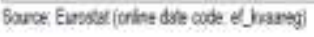

Figure 1: Share of farms in the EU-28 and Romania, by size class (\%)

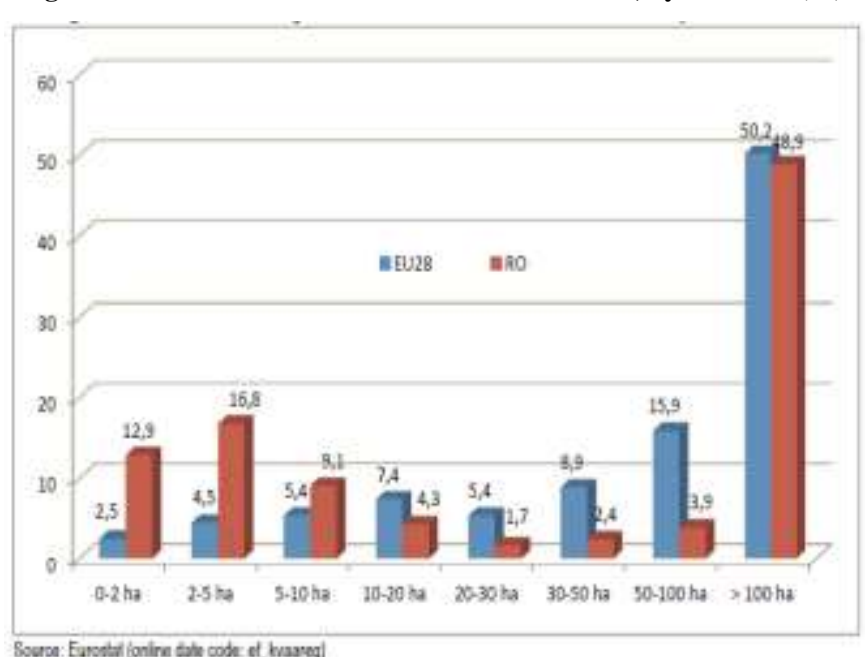

Figure 2: Share of utilized agricultural area in the EU-28 and Romania, by size class $(\%)$

There are however a number of EU countries where the average size exceeds several times the European average: Czech 152.4 ha; UK 90.4 ha; Slovakia 77.5 ha; Denmark 62.9 ha; Luxembourg 59.6 ha; Germany 55.8 ha, France 53.9 ha; Estonia 48.0 ha; Sweden 43.1 ha.
TABLE I. NUMBER OF EXPLOITATIONS VS. THE AVERAGE SIZE OF FARMS IN EU-28

\begin{tabular}{|c|c|c|c|}
\hline \multirow{2}{*}{ Tara } & \multicolumn{2}{|c|}{$\begin{array}{l}\text { Număr de } \\
\text { exploatații }\end{array}$} & \multirow{2}{*}{$\begin{array}{l}\text { Dimensiune } \\
\text { medie } \\
\text { (ha) }\end{array}$} \\
\hline & (mii) & $\%$ & \\
\hline UE-28 & 12248 & 100,00 & 14,2 \\
\hline RO & 3859,0 & 31,51 & 3,45 \\
\hline IT & 1620,9 & 13,23 & 7,9 \\
\hline PL & 1506,6 & 12,30 & 9,6 \\
\hline ES & 989,8 & 8,08 & 24,0 \\
\hline EL & 723,0 & 5,90 & 4,8 \\
\hline $\mathrm{HU}$ & 576,8 & 4,71 & 8,1 \\
\hline FR & 516,1 & 4,21 & 53,9 \\
\hline $\mathrm{BG}$ & 370,5 & 3,02 & 12,1 \\
\hline $\mathrm{PT}$ & 305,3 & 2,49 & 12,0 \\
\hline $\mathrm{DE}$ & 299,1 & 2,44 & 55,8 \\
\hline HR & 233,3 & 1,90 & 5,6 \\
\hline LT & 199,9 & 1,63 & 13,7 \\
\hline UK & 186,8 & 1,53 & 90,4 \\
\hline $\mathrm{AT}$ & 150,2 & 1,23 & 19,2 \\
\hline IE & 139,9 & 1,14 & 35,7 \\
\hline $\mathrm{LV}$ & 83,4 & 0,68 & 21,5 \\
\hline SI & 74,7 & 0,61 & 6,5 \\
\hline NL & 72,3 & 0,59 & 25,9 \\
\hline SE & 71,1 & 0,58 & 43,1 \\
\hline FI & 63,9 & 0,52 & 35,9 \\
\hline $\mathrm{BE}$ & 42,9 & 0,35 & 31,7 \\
\hline DK & 42,1 & 0,34 & 62,9 \\
\hline $\mathrm{CY}$ & 38,9 & 0,32 & 3,0 \\
\hline SK & 24,5 & 0,20 & 77,5 \\
\hline $\mathrm{CZ}$ & 22,9 & 0,19 & 152,4 \\
\hline $\mathrm{EE}$ & 19,6 & 0,16 & 48,0 \\
\hline MT & 12,5 & 0,10 & 0,9 \\
\hline LU & 2,2 & 0,02 & 59,6 \\
\hline
\end{tabular}

In Romania, agricultural land fund is strongly affected by the crumbling plots small, leading in many cases to the impossibility of applying modern agricultural technology leading, scientifically, to obtain cropland of stable production both in terms of quantity but also in quality. Agricultural production is supported by the majority of small farms and therefore the performance of agriculture in Romania is affected by excessive fragmentation of ownership.

On the other side in Romania there is a category of large farms and very large surface area of over 100 ha, representing $0.4 \%$ of total holdings (13730 holdings), but that uses the $48.9 \%$ of the utilized agricultural area at national level.

According to the farm structure survey in 2013, the number of small agricultural holdings, who used an agricultural area of up to 1 hectare decreased in 2013 compared to 2010 by about 76 thousand farms, respectively $3.8 \%$, they holding still a very significant proportion of $54.5 \%$ of the total. The decrease in the number of farms has contributed small farms that used an agricultural area less than 0.1 hectares, which account for a percentage of $11 \%$ of total holdings [18].

The phenomenon of structural duality of farms maintain, requiring a lengthy process to effect the restructuring at farm level. Although the total number of farms decreased in 2002-2013 with over 850 thousand, from 4.485 billion farms in 2002 to 3.630 billion farms in 2013, was maintained structure extremely divided Romanian agriculture and subsistence character of the vast majority of farms.

Results that Romania is characterized by a highly polarized agrarian structure. Such pronounced bipolar distribution, 
with the majority of agricultural land divided, on the one part, the extremely modest farm physical and economic size, which produce mainly for their own needs, do not invest and do not generate consumer market, and on the other part a relatively small number of farms producing industrial system and adopt modern technologies, the main factor limiting the increase of competitiveness of Romanian agriculture $[17,20]$.

With this reality agrarian structure excessively broken, it is considered that for a medium-term strategy, the problem should be approached differently medium and large farms, which are farms professional and make agriculture a business and the small farms that have a less important role in the markets, but are important in the rural world for providing food and social security, contribute to environmental preservation through the use of traditional production methods, etc.

Restructuring activities at farm level and increased use of capital for commercial farms will lead to improved competitiveness and inevitably to the use of a smaller workforce. The farm building involves increasing the physical size and economically. In parallel with the increase in farm size is achieved specialization of farms, an increase of the economic importance of large holdings.

The major importance of agriculture in rural Romanian economy is generated that utilized agricultural area of farms by commercial type, efficient and competitive, it is approximately equal to that which is practiced subsistence agriculture [14].

Nonperformance of agricultural production is generated firstly from dependence still (too) high annual meteorological conditions because irrigation systems are largely degraded and inoperative equipment precarious farms with irrigation systems and high cost of water irrigation, but also through the use of agricultural technologies obsolete, with low consumption of inputs that support performance (quality seed, fertilizers, substances for crop protection) and technical equipment outdated in terms of energy consumption and productivity [8].

Romania is characterized by a highly polarized agrarian structure. Such distribution emphasized pole, mostly agricultural land divided between holdings extremely modest in size physical and economic, that produce mainly for its own needs, do not invest and do not generate consumer market, and, on the other hand, a relatively small number of farms producing in industrial system and adopt modern technologies, is the main factor limiting the growth of competitiveness of Romanian agriculture.

Starting from this reality on agrarian structure excessively fragmented, the problem farms medium and large should be approached differently from that of small farms because both types have their importance: medium-sized farms and large, that are firm professional make agriculture a business and are particularly important in providing agricultural products for the market and small ones, which have a commercial role less important, it is important to the rural world because it provides food security and social development, contributing to environmental preservation through the use of production methods traditional.
Near from the Community structures has produced and still produces significant changes, especially on the growth and importance of the role of producer for the market, and medium and large farms. Restructuring of the sector is inevitable but because in terms of economic performance remains below the European farms. These units, however, have considerable potential resources, high average yields and become competitive on the EU market and export. Their role should increase in the development of animal husbandry product network integration within large companies, and large individual holdings and cooperation with associations. [15].

So far there have been advantaged large farms on the application of advanced technologies due to large surfaces, access to credit to modernize the equipment, the financial resources necessary use of superior biological categories varieties, animal breeds higher. They also have advantages for managerial heads of farms or companies that are, in most cases, qualified individuals with extensive experience. As a result achieved average yields per hectare and the upper small animal farms, cereals, oilseeds, viticulture, in some animal species. The performance of this sector is facilitated by the existence of accounting and statistical information missing in small farms.

Farm consolidation process involves increasing the physical size, and hence their economic crises. Parallel to increased farm size, it is necessary to undertake a specialization of farms, an increase in the economic importance of large farms. The process is naturally closely linked with the emergence of new agricultural technologies more efficient.

Consolidation of family farms small and medium organized in various forms of cooperation in the domains of a product is important in the context of the financial crisis and global climate change since they can provide, on the one hand feed rural families, on the other hand can produce to market a wide range of products: organic and traditional products made from local resources [11].

Sector commercial family farms can form as a result of measures to support semi-subsistence farms and bolstering existing family farms producing for the market by facilitating access to European Structural Funds.

Measures to support subsistence farms to become sustainable, provided the NRDP and funded in 2009, is a beneficial solution for their modernization, purchase of equipment and technologies for merging, combining, lease or purchase land.

With the improvement of technology and more efficient use of resources, small farmers not participating in the competition to reduce costs will inevitably face pressures on revenue. Faced with these pressures have only two options, either to reach the level and size efficient commercial producers, or to seek to obtain additional income from other sources, diversification of revenue sources.

Increasing the size of holdings will occur naturally if farming becomes a profitable activity: farmers seek to increase the area of the holding in an environment where they can earn enough from agriculture $[3,6]$. It is therefore necessary to implement policies that will enable farmers to improve their financial performance through extension services and training to small farmers in farm management, the development of networks of marketing and supply in 
agriculture, including encouraging cooperatives services for small farmers [4].

Romania presents significant gaps compared to EU agricultural sector productivity. Even in favorable crop years, productivity is below $50 \%$ of the EU average economic situation showing untapped potential of Romanian agriculture and rural areas. This can be explained both by the internal structure of the Romanian farms (small size, fragmentation accentuated), the inappropriate use of inputs (including human capital) and the existing poor infrastructure. In particular, the lack of infrastructure to exploit agricultural products is a critical issue for small farms [10].

Agricultural production obtained in farms in Romania is not stable, it is not predictable and varies depending on the area under cultivation, livestock and yields per hectare and per animal.

The current state of the market food products reflect gaps between supply and demand components. Demand is met entirely from domestic production only for cereals and cereal products. For other products, availability of domestic consumption is formed from domestic production and imports. They hold significant shares in the total supply for certain products: legumes, meat and meat products, fish and fish products.

To reduce imports of food products, offer should be the primary form of domestic production, which can grow about extensive by increasing the cultivated area, or about intensive by increasing the average production per hectare.

Trade in agricultural products in Romania is currently disorganized and weak quantitative and seasons, especially in agricultural products of plant origin, which are seasonal. The sector can cover the daily needs of consumers, particularly in large urban settlements. To cover the expense, offer food market is complemented by imports from Turkey, Greece, Spain etc, especially vegetables and fruits.

To enhance the efficiency of distribution of food products is necessary emergence and development of associative forms of collection and marketing chains in the early stages of the agri-food system. On the experience of old EU Member States to organize distribution of food systems requires the establishment of specific distribution links: associations of producers.

Lack of organization of small farmers in professional organizations is a major impediment to negative effects on the organization of product chains, negotiating prices of agricultural products, knowledge that can access the facilities from the point of view of obtaining the necessary funds' investments.

The evolution of the agri-food sector in Romania requires a high level of technical, economical and business management at farm level in order to successfully fulfill EU standards (food safety, animal health, environmental standards, etc.) and face a competitive environment.

Improving the knowledge and skills of farmers will contribute to the restructuring / modernization of farms (small and medium), range of products, market orientation of small farms, the adoption of innovative technologies and best practices, especially by young farmers and creation of short supply chains. It will also be encouraged sustainable management of natural resources and adaptation to climate change [9, 12].

One of the European Commission's priorities for 2020 is inclusive growth, along with a smart and sustainable growth. This will put more emphasis on human resource development, education and develop their skills, lifelong learning, promote social inclusion, increasing employment, reducing poverty, and strengthening administrative capacity $[2,19]$.

\section{Restructuring holdings through the National Program for Rural Development}

In 2007-2013, the National Rural Development Programme (NRDP) included two measures with a direct effect on strengthening holdings, the proposed European regulation in an attempt to speed up structural transformation of agriculture to the new Member States (that joined the EU after 2004). It is transitional measures 141 "Supporting semi-subsistence farms" and 142 "Setting up of producer groups", designed to speed up market integration smaller farms $[7,21]$.

By the measure 141 semi-subsistence farms could be supported to restructure individually, based on a development plan which included better integration market, as long as the measure 142 aid has been granted for a collective activity integration market through joint marketing of the products.

If the measure 141 assumed increasing its sales through a form of vertical coordination of production (sale on an organized market or integration into a branch on the basis of firm contracts), the measure 142 encourage the association to market production through horizontal coordination among farmers by setting up producer groups, with a special contribution to the agri-food sector structuring of Romania.

TABLE II. SITUATION MEASURES 141 AND 142 PROJECTS UNDER THE NRDP 2007-2013

\begin{tabular}{|c|c|c|}
\hline \multirow{2}{*}{ Measures } & \multicolumn{2}{|c|}{ Submitted projects } \\
\hline & Number. & Public value \\
\hline 141 & 88.846 & 666.345 .000 \\
\hline 142 & 86 & 16.870 .702 \\
\hline \multirow{2}{*}{ Measures } & \multicolumn{2}{|c|}{ Selected projects } \\
\hline & Number. & Public value \\
\hline 141 & 63.544 & 476.580 .000 \\
\hline 142 & 80 & 15.560 .049 \\
\hline \multirow{2}{*}{ Measures } & \multicolumn{2}{|c|}{ Financing contracts signed } \\
\hline & Number. & Public value \\
\hline 141 & 53.348 & 377.029 .184 \\
\hline 142 & 58 & 11.921 .945 \\
\hline \multirow{2}{*}{ Measures } & \multicolumn{2}{|c|}{ Payments made } \\
\hline & \multicolumn{2}{|c|}{ Public value } \\
\hline 141 & \multicolumn{2}{|c|}{333.378 .187} \\
\hline 142 & \multicolumn{2}{|c|}{5.254 .616} \\
\hline
\end{tabular}

Sources: MARD, the General Directorate of Rural Development NRDP

\section{Conclusions}

The main measures of Romanian agricultural restructuring, reduction and gradual elimination of structural gaps between agriculture Romania and other EU Member States, and to increase physical and economic size of farms, aims to:

- The optimal use of natural conditions of soil and climate of human resources is often, materials and financial capabilities farms; 
- Concentration of agricultural production in larger units to produce for the market in terms of economic efficiency, social and environmental;

- Increasing mechanization of farming, increasing labor productivity and yields while reducing production spending severely;

- Stabilization of quantitative and qualitative supply of agricultural products by improving the quality of inputs and technology culture;

- Initiating and supporting the formation of individual associations of agricultural producers for the supply of inputs for executing mechanical works for the storage of products obtained and the effective use of the products obtained;

- Accelerate the restructuring of farms by increasing territorial and economic dimensions to form medium farm sector, the concentration of supply for marketing, while organizing small farmers in various forms of association and cooperation on product chains to ensure increased market competitiveness and income rural residents;

- Improving production structures to meet domestic consumer demand and exports by diversifying economic activities in rural areas;

- Promoting sustainable production and consumption model by increasing food production and sustainable ways of product quality;

- Increase value added and labor productivity on farms by economic organization of farmers, improving the use of agricultural resources and using financial support from the European Union and the national budget for restructuring activities and investment holdings;

- Organizing the routes of food products (production, storage, processing, distribution) having the effect of increasing the competitiveness of agriculture.

Increasing the size of holdings will occur naturally if you become a profitable agriculture: farmers seek to increase the holding area in an environment where they can earn enough from farming.

Restructuring of agriculture will have a major impact on the rural economy in general, given that agriculture remains the most important activity in rural areas and an essential source of income for households.

Romanian agricultural and rural sector continues to have a substantial growth potential, yet underutilized agricultural restructuring and revitalizing the rural economy representing major levers of economic development of Romania.

The deepening the integration process of adoption and implementation of European standards on quality, food security, infrastructure development compatible with the European Union, development and stabilize agricultural markets and strengthening cooperatives in agricultural production creates the conditions for efficient agricultural labor at farm level Romanian agriculture.

Small farms should be streamlined and targeted in the next period by the market. Creating institutional environment and infrastructure for the development of products obtained will be the major element for improving the economic performance of farms.

\section{References}

[1] Bold I., Crăciun A.(2001) Agricultural holding, Mirton Publisching, Timişoara

[2] Condei Reta, Mocuta Dorina, Popescu Agatha, Turek Rahoveanu A. (2015) - The importance of as sessing human resources for the sustainable development - a study case, South West Oltenia Region, Scientific Papers Series : „Management, Economic Engineering in Agriculture and Rural Development", Vol. 15; Issue 1

[3] Dobre Iuliana (2003) - Managementul structurii de producţie în exploataţiile agricole, Editura ASE, Bucharest

[4] Dobre Iuliana (2012) the Knowledge Implications on Performance Management of Agricultural Production Structure - International Comparative Management, Vol. 13 (1)

[5] Dobre Ramona, Cîrstea A. C. (2013) - Land property structure - a limiting factor in strengthening the agricultural holdings, Scientific Papers Series Management, Economic Engineering in Agriculture and Rural Development, Vol. 13, Issue 2

[6] Luca L., Cristina Cionga, Daniela Giurcă, (2012) - Consolidarea exploatațiilor agricole, Comisia Națională de Prognoză

[7] Luca L. (2013) Evaluation of Agricultural Policy in Romania in terms of food security, Romanian Academy, Bucharest

[8] Otiman P.I. (2012) - Structura agrară actuală a României - o mare (şi nerezolvată) problemă socială și economică a țării, ,Revista Română de Sociologie", serie nouă, anul XXIII, nr. 5-6, p. 339-360, București

[9] Popescu G., Andrei J., (2010), Aspects Regarding the Relationship between Proprietary and Economic Entrepreneurship in the Romanian Agricultural Economics, The 14th IBIMA Conference on Global Business Transformation through Innovation and Knowledge Management, Istanbul, Turkey

[10] Turek Rahoveanu A. (coordonator), Turek Rahoveanu Magdalena, Ion Raluca, Radu V. (2011) Optimizarea structurilor de producție necesitate pentru asigurarea competitivității exploatațiilor agricole, Editura Terra Nostra, ISBN 978-973-1888-79-8

[11] Turek Rahoveanu, A., Turek Rahoveanu, Magdalena (2012), Agricultural structure in the South of Romania and agriculture development opportunities; Proceedings of the International scientific meeting: „Sustainable agriculture and rural development in terms of the Republic of Serbia strategic goals implementation within Danube Region - preservation of rural values“, pg. 991-1006, ISBN 978-866269-018-0

[12] Turek Rahoveanu A. (2013), Sustainable Technologies, Policies and Constraints in the Green Economy, Chapter: Sustainable Agriculture: Between Sustainable Development and Economic Competitiveness; IGI Global Publishing, USA, ISBN 978-1-466-64098-6

[13] Turek Rahoveanu A., Stoian Elena, Turek Rahoveanu Magdalena (2013) - Analysis of the exploitation structures and land management in Romania vs. European Union; International Journal of Sustainable Economies Management, Vol.2, Issues 4, pg. 47-54, ISSN 2160 -9659

[14] Zahiu Letitia (coord). (2005) Policies and agricultural markets reform and European integration, Ceres Publishing, Bucharest

[15] Zahiu Letiţia, Dachin Anca, Turek Rahoveanu A. (2007) - Factorii care influentează performanța economică în fermele mari din România, Dezvoltarea durabilă a spaţiului rural", ASE, Facultatea de Economie Agroalimentară şi a Mediului, Bucureşti, 15-16 iunie 2007, volum ISBN 978-606-505-025-9

[16] Zahiu Letitia (coordonator) (2010) - Agricultura în economia României - între aşteptări și realități, Editura Ceres, București

[17] *** Socio-economic rural development perspective 2014-2020, (2013) MARD.

[18] *** Ancheta Structurală în Agricultură 2013 - rezultate finale, INS 2014

[19] *** National Strategie 2014-2020-2030 (2013), the Presidential Commission for Public Policy for Agricultural Development

[20] *** Study on Consolidation of farms (2012), the National Commission for Prognosis

[21] *** Comisia prezidenţială pentru politici publice de dezvoltare a agriculturii - Cadrul Strategic National de Dezvoltare Durabilă a spațiului rural românesc în 2014 - 2020 - 2030 